\title{
Penurunan Kadar Surfaktan dan Sulfat dalam Limbah Laundry
}

\author{
Nani Apriyani \\ Program Studi Teknik Lingkungan Universitas Muhammadiyah Palangkaraya \\ email: nani.apriyani@umpalangkaraya.ac.id
}

\begin{abstract}
ABSTRAK. Jasa pencucian (laundry) di Indonesia yang semakin meningkat setiap tahunnya diiringi dengan terjadinya pencemaran lingkungan khususnya air akibat limbah yang dihasilkan. Detergen merupakan produk pembersih yang umumnya digunakan dalam proses laundry dengan kandungan utamanya adalah surfaktan dan fosfat dalam builder. Hal ini menyebabkan limbah laundry memiliki kandungan surfaktan dan fosfat yang cukup tinggi. Seiring bertambahnya kegiatan jasa laundry tersebut, maka perlu adanya pengelolaan limbah guna menurunkan kadar surfaktan dan fosfat akibat limbah yang dihasilkan. Beberapa metode yang telah dilaporkan dapat menurunkan kadar surfaktan dan fosfat adalah biodegradasi, elektrokoagulasi, membran dan biofiler.
\end{abstract}

Kata kunci : limbah, laundry, surfaktan, sulfat, pencemaran

\section{PENDAHULUAN}

Kegiatan jasa pencucian (laundry) di Indonesia semakin meningkat setiap tahunnya. Jasa ini memiliki manfaat besar bagi masyarakat, baik bagi penyedia maupun pengguna jasa laudry tersebut. Seiring bertambahnya kegiatan jasa ini maka perlu diikuti dengan pengelolaan guna mencegah terjadinya pencemaran akibat limbah yang dihasilkan.

Dalam prakteknya, jasa laundry banyak menggunakan deterjen sebagai bahan pencuci dikarenakan deterjen mempunyai sifat-sifat pembersih yang efektif dibandingkan dengan sabun biasa. Zat utama yang terkandung dalam deterjen adalah senyawa ionik berupa natrium tripolifospat yang berfungsi sebagai builder dan surfaktan (Wardhana dkk., 2009).

Menurut Masduqi melaporkan bahwa dalam sehari usaha laundry di Daerah Keputih Sukolilo, Surabaya bisa mengerjakan cucian sekitar 75 sampai 80 $\mathrm{kg}$ dan air limbah laundry yang dihasilkan sebesar 35 sampai 40 liter dengan konsentrasi fosfat yang terkandung dalam air limbah laundry tersebut sebesar $7,40 \mathrm{mg} / \mathrm{L}$ (Wandhana, 2013). Berlebihnya kandungan fosfat dalam badan air dapat mengakibatkan terjadinya algae blooming atau eutrofikasi.

Kasus di atas hanya merupakan salah satu dampak tercemarnya air akibat limbah laundry. Beberapa metode untuk menurunkan konsentrasi zat pencemar dari limbah laundry banyak dilaporkan sebagai upaya menanggulangi pencemaran air. Tulisan ini bertujuan memberikan informasi tentang beberapa metode tersebut untuk menjaga dan menanggulangi pencemaran lingkungan.

\section{PEMBAHASAN}

\section{Kandungan Detergen}

Detergen merupakan produk pembersih yang merupakan penyempurnaan dari sabun. Kelebihan deterjen dibandingkan sabun adalah kemampuannya dalam mengatasi air sadah dan larutan asam. Detergen sering disebut dengan istilah detergen sintetis yang dibuat dari bahan-bahan sintetis (Zoller, 2004). 
Deterjen mengandung sekitar 25 macam bahan yang secara umum dapat dikelompokan menjadi: (1) surfaktan, (2) builder, (3) bleaching agents dan (4) additives (Smulders, E., 2002). Komponen terbesar dari detergen yaitu bahan builders antara $70-80 \%$, bahan dasar sekitar 20-30\%, dan bahan aditif relatif sedikit antara $2-8 \%$.

Pemakaian detergen akan menghasilkan limbah karena setelah pemakaian, air bekas cucuian yang telah mengandung deterjen dibuang di lingkungan. Formulasi awal detergen mengandung surfaktan nonbiodegradabel. Air limbah detergen termasuk polutan bagi lingkungan karena mengandung zat ABS (alkyl benzene sulphonate) yang tergolong keras. Surfaktan sebagai komponen utama dalam detergen memiliki rantai kimia yang sulit didegradasi alam (Sutanto, 1996).

\section{Limbah Detergen: Surfaktan}

Surfaktan (surfactant: surface active agents) merupakan senyawa yang dapat menurunkan tegangan permukaan air. Surfaktan berfungsi untuk mengangkat kotoran pada pakaian baik yang larut dalam air maupun yang tak larut dalam air. Hal ini dapat terjadi karena molekul surfaktan terdiri dari satu ujung hidrofilik dan satu ujung hidrofobik (satu rantai hidrokarbon atau lebih). Ujung hidrofobik surfaktan merupakan satu rantai atau lebih hidrokarbon yang mengandung 12 atom karbon atau lebih.

Molekul-molekul dan ion-ion yang diadsorbsi pada antar muka inilah yang dinamakan surface aktive agent atau surfaktan. Surfaktan disebut juga sebagai amfifil karena molekul atau ionnya yang mempunyai affinitas tertentu terhadap pelarut polar maupun non polar. Hal ini tergantung pada jumlah dan sifat dari gugusgugus polar dan non polar tersebut. Amfifil dapat bersifat hidrofilik (suka air), lipofilik (suka minyak) atau bersifat seimbang di antara dua sifat ekstrim tersebut. Struktur dari surfaktan terlihat seperti Gambar 1.

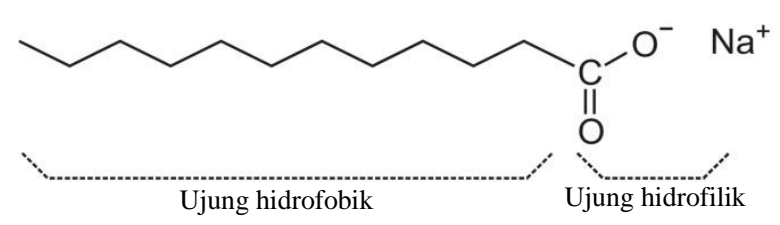

Gambar 1. Struktur surfaktan

Surfaktan dikelompokan menjadi empat kelompok yaitu anionik, nonionik, kationik, dan zwitterionik atau amfoterik (Smulder, E., 2002 \& Yu, et al, 2008). Contoh surfaktan ditampilkan dalam Tabel 1.

Tabel 1. Contoh surfaktan

\begin{tabular}{lcc}
\hline \multicolumn{1}{c}{ Surfaktan } & \multicolumn{1}{c}{ Rumus molekul } & Jenis \\
\hline $\begin{array}{l}\text { Alkil } \\
\text { (polietilen) } \\
\text { glikol ether }\end{array}$ & $\mathrm{RO}-\left(\mathrm{CH}_{2}-\mathrm{CH}_{2}-\mathrm{O}\right)_{\mathrm{n}} \mathrm{H}$ & Nonionik \\
$\begin{array}{l}\text { Alkil } \\
\text { Sulfonat }\end{array}$ & $\mathrm{RO}-\mathrm{SO}_{3}^{-} \mathrm{Na}^{+}$ & Anionik \\
$\begin{array}{l}\text { Dialkil } \\
\text { Dimetil }\end{array}$ & {$\left[\mathrm{H}_{3} \mathrm{C}-\mathrm{N}^{+}(\mathrm{R})_{2}-\mathrm{CH}_{3}\right] \mathrm{Cl}^{-}$} & Kationik \\
$\begin{array}{l}\text { amonium } \\
\text { klorida }\end{array}$ & \\
Betaines & $\mathrm{R}-\mathrm{N}^{+}\left(\mathrm{CH}_{3}\right)_{2}-\mathrm{CH}_{2}-\mathrm{COO}^{-}$ & Amfoterik \\
\hline \multicolumn{2}{l}{ (Sumber: Smulder, E., 2002) }
\end{tabular}

Jenis surfaktan anionik merupakan jenis yang paling banyak digunakan dalam kegiatan laundry karena biaya pembuatannya yang mudah dan murah. Surfaktan anionik yang umum digunakan adalah Alkyl Benzene Sulfonates (ABS) dan Linear Alkyl Benzene Sulfonates (LAS) (Yu, et al, 2008).

ABS dikenal sebagai deterjen karena yang tahan terhadap penguraian biologis, sehingga dikenal sebagai senyawa pencemar toksik bagi biota air (Chonnell dalam Hudori, 2008). Penggunaannya kemudian digantikan dengan LAS pada tahun 1965.

LAS dapat menurunkan tegangan permukaan dan mengemulsi lemak sehingga sebagai dimanfaatkan sebagai pelarut lemak dan denaturasi protein. Jenis surfaktan lainnya juga digunakan sebagai pembersih pakaian seperti Nonylphenol dan Sodium Lauryl Ether Sulphate dari kelompok surfaktan nonionik (Hudori, 2008; Yu, et al, 2008). Struktur LAS dapat dilihat pada Gambar 2. 


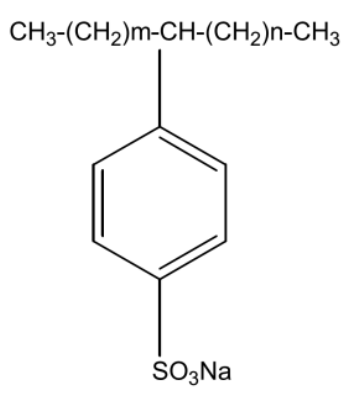

Gambar 2. Struktur Linear Alkyl Benzene

Sulfonates; LAS: $\mathrm{C}_{\mathrm{n}} \mathrm{H}_{2 \mathrm{n}}-\mathrm{SO}_{3} \mathrm{Na}$

( $\mathrm{n}=16-20$, untuk produk komersial)

\section{Limbah Detergen: Fosfat}

Komponen penting kedua penyusun deterjen adalah builder. Fungsi builder dalam deterjen adalah melunakkan air sadah dengan cara mengikat mineral terlarut agar surfaktan dapat berfungsi dengan baik.

Builder dapat membantu terciptanya suasana asam yang tepat agar proses pembersihan berlangsung dengan lebih baik serta membantu mensuspensikan kotoran yang telah lepas. Senyawa kompleks yang umum digunakan dalam builder adalah natrium sitrat, natrium karbonat, natrium silikat, flourescent dan fosfat (Hudori, 2008).

Jenis builder yang sering digunakan dalam deterjen adalah Sodium Tripolifosfat (STPP) (Tjandraatmadja dan Diaper, 2006). Struktur STTP dapat dilihat pada Gambar 3. STPP bereaksi dengan ion magnesium dan ion kalsium dalam air untuk mengurangi keberadaan ion-ion tersebut karena dapat mengurangi efektivitas surfaktan. Reaksi tersebut membentuk padatan dan senyawa lain yang juga mengandung fosfat dan digunakan untuk mencegah kotoran menempel kembali. Padatan yang terbentuk akibat reaksi tersebut akan lebih tinggi bila air yang digunakan memiliki tingkat kesadahan tinggi, dan sebaliknya (Kohler, 2006; Hudori, 2008; Yu, et al, 2008).<smiles>O=P([O-])([O-])OP(=O)([O-])OP(=O)([O-])O</smiles>

Gambar 3. Struktur Sodium Tripolifosfat (STTP)

Deterjen yang mengandung fosfat akan menghasilkan limbah yang mengandung polifosfat, yang merupakan salah satu bentuk dari fosfor selain fosfor organik dan orthofosfat $\left(\mathrm{H}_{2} \mathrm{PO}_{4}^{-}, \mathrm{HPO}_{4}{ }^{2-}, \mathrm{PO}_{4}{ }^{3-}\right)($ Hammer dan Viesman, 2005).

Adanya fosfat dalam air dapat menghambat penguraian pada proses biologis (Saefumilah, 2006). Fosfat merupakan bentuk persenyawaan fosfor yang berperan penting sebagai penunjang kehidupan aquatik. Penggunaan deterjen dapat meningkatkan konsentrasi fosfat pada badan air buangan sehingga memicu pertumbuhan algae (Paytan \& McLaughin, 2007).

Fosfat tidak memiliki daya racun, tetapi akumulasinya dalam jumlah berlebihan dapat menyebabkan pengkayaan unsur hara atau eutrofikasi yang ditandai dengan terjadinya ledakan pertumbuhan tanaman air sehingga menyebabkan pencemaran air (Widiyani, 2010).

\section{Metode Pengolahan Limbah Laundry}

Beberapa penelitian tentang metode pengolahan limbah laundry disajikan dalam Tabel 2.

Tabel 2. Penelitian tentang metode pengolahan limbah laundry

\begin{tabular}{clll}
\hline Tahun & \multicolumn{1}{c}{ Peneliti } & \multicolumn{1}{c}{ Metode } & Tujuan \\
\hline- & Argo Hadi Kusumo & Adsorpsi Menggunakan Arang Batok & Penurunan Konsentrasi \\
& M. Razif & Kelapa (Coconut Shells) Komersil & Surfaktan \\
\hline- & Budiany Rachmawati & Elektrokoagulasi & $\begin{array}{l}\text { Penurunan Konsentrasi } \\
\text { Yayok Surya P }\end{array}$ \\
& Mohamad Mirwan & & Surfan \\
\hline- & Satria Pratama Putra Nasution & Reaktor Biofilter & Pemulihan Kualitas Air \\
& Nieke Karnaningroem & & Limbah Laundry \\
\hline 2009 & Budiawan, & Biodegradabilitas & Alkilbenzena Sulfonat (LAS) \\
& Yuni Fatisa, & & Alburfaktan Linear \\
& Neera Khairani & & \\
\hline
\end{tabular}




\begin{tabular}{|c|c|c|c|}
\hline 2009 & $\begin{array}{l}\text { Hudori, } \\
\text { P. Soewondo }\end{array}$ & $\begin{array}{l}\text { Elektrokoagulasi Dengan Elektroda } \\
\text { Aluminium }\end{array}$ & Pengolahan Deterjen \\
\hline 2012 & $\begin{array}{l}\text { Novia Rahmawati, } \\
\text { Ratih Purnamasari }\end{array}$ & $\begin{array}{l}\text { Koagulasi-Flokulasi, Filtrasi Dan } \\
\text { Adsorbsi }\end{array}$ & Penyisihan Kekeruhan \\
\hline 2012 & Cony Puspitahati & Biosand Filter & $\begin{array}{l}\text { Penurunan Kandungan } \\
\text { Phosphat }\end{array}$ \\
\hline 2013 & $\begin{array}{l}\text { Vera Roni Setiawan, } \\
\text { Cut Meurah Rosnelly, } \\
\text { Darmadi }\end{array}$ & $\begin{array}{l}\text { Membran Selulosa Diasetat Berbasis } \\
\text { Selulosa Pulp Kayu Sengon } \\
\text { (Paraserianthes Falcataria) }\end{array}$ & $\begin{array}{l}\text { Pengolahan Limbah Cair } \\
\text { Laundry }\end{array}$ \\
\hline 2013 & $\begin{array}{l}\text { Irawan Wisnu Wardhana, } \\
\text { Dwi Siwi H., } \\
\text { Dessy Ika R. }\end{array}$ & $\begin{array}{l}\text { Penggunaan Karbon Aktif Dari } \\
\text { Sampah Plastik }\end{array}$ & $\begin{array}{l}\text { Penurunan Kandungan } \\
\text { Phosphat }\end{array}$ \\
\hline 2013 & Ni Made Yunarsih & $\begin{array}{l}\text { Membran Khitosan dari Kulit Udang } \\
\text { Galah (Macrobanchium Rosenbergii) }\end{array}$ & Penurunan Fosfat \\
\hline 2013 & Anggi Rizkia Utami & Biosand Filter dan Activated Carbon & $\begin{array}{l}\text { Pengolahan Limbah Cair } \\
\text { Laundry }\end{array}$ \\
\hline 2013 & $\begin{array}{l}\text { Aufiyah, } \\
\text { Alia Damayanti }\end{array}$ & $\begin{array}{l}\text { Membran Nanofiltrasi Aliran } \\
\text { Cross Flow }\end{array}$ & Penurunan Fosfat \\
\hline 2015 & Haryati Bawole Sutanto, & $\begin{array}{l}\text { Kombinasi Sistem Biofilter dan } \\
\text { Tanaman Air }\end{array}$ & $\begin{array}{l}\text { Penurunan Kandungan COD, } \\
\text { Detergen dan Nutrien } \\
\text { (Phospat) }\end{array}$ \\
\hline 2015 & $\begin{array}{l}\text { Sri Widya Astuti, } \\
\text { Mersi Suriani Sinaga }\end{array}$ & Metode Biosand Filter & Degradasi Fosfat \\
\hline 2015 & $\begin{array}{l}\text { Ni G. A. M Dwi Adhi Suastuti, } \\
\text { I Wayan Suarsa, } \\
\text { Dwi Kurnia Putra R }\end{array}$ & $\begin{array}{l}\text { Biofilter Tanaman Kangkungan } \\
\text { (Ipomoea Crassicaulis) dalam Sistem } \\
\text { Batch (Curah) Teraerasi }\end{array}$ & $\begin{array}{l}\text { Penurunan Konsentrasi } \\
\text { Surfaktan dan Fosfat }\end{array}$ \\
\hline
\end{tabular}

Berdasarkan Tabel tersebut, dapat dikelompokkan metode pengolahan limbah laundry yaitu: (1) biodegradasi, elektrokoagulasi, (3) membran dan (4) biofilter.

\section{Biodegradasi}

Salah satu metode pengolahan limbah secara biologi adalah biodegradasi, yaitu proses oksidasi senyawa organik oleh mikroorganisme, baik di tanah, perairan, atau pada instalasi pengolahan air limbah. Proses ini dapat terjadi karena adanya metabolisme zat organik melalui sistem enzim untuk menghasilkan karbon dioksida, air, dan energi oleh bakteri.

LAS bersifat mudah dibiodegradasi hingga $95-99,9 \%$ pada metode pengolahan limbah cair dengan lumpur aktif (Prats dkk, 2006). Biodegrasi LAS dapat dilakukan di bawah kondisi aerobik pada media yang mengandung air, meskipun sejumlah 20-25\% fraksi penting terimobilisasi dalam limbah padat dan persisten dalam kondisi aerobik (Peinado, 2009). Dalam kondisi anaerobik, sangat sedikt LAS yang dapat didegradasi. Hal ini terjadi dikarenakan rantai alifatik tidak dapat direduksi lebih lanjut.
Beberapa bakteri yang telah dilaporkan dapat melakukan biodegradasi adalah Flavobakterium sp., Acinetobacter sp., Pseudomonas spp. yang dapat tumbuh pada beberapa aromatik sulfonat, dan bakteri alami Comamonas testosteroni $\mathrm{T}-3$, yang mampu mendegradasi P-toluen-sulfonat (pTS) sebagai model senyawa aromatik (WHO, 1996).

\section{Elektrokoagulasi}

Elektrokoagulasi adalah proses destabilisasi suspensi, emulsi dan larutan yang mengandung kontaminan dengan cara mengalirkan arus listrik melalui air sehingga membentuk gumpalan yang mudah dipisahkan (Mollah, 2004). Proses elektrokoagulasi menurut Susetyaningsih merupakan gabungan proses elektrokimia dan koagulasi-flokulasi dan elektrokimia (Retno, dkk 2008). Tiga proses mendasar dalam elektrokoagulasi ini dinyatakan dalam Diagram Venn pada Gambar 4 berikut. 


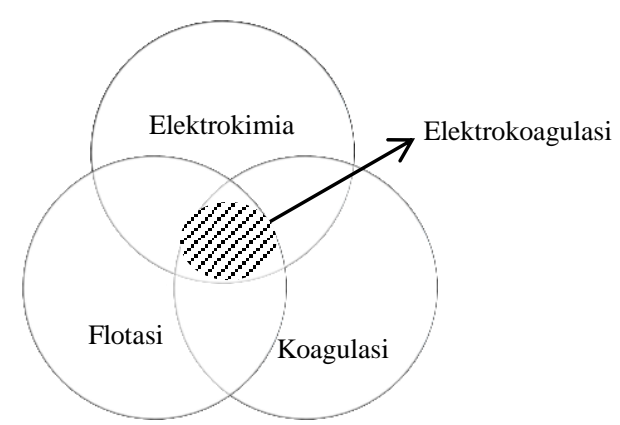

Gambar 4. Diagram Venn elektrokoagulasi (Holt et al., 2001)

Pada elektrokoagulasi terjadi reaksi oksidasi-reduksi. Proses ini timbul karena adanya reaksi pada elektroda sebagai akibat masuknya aliran arus listrik searah dengan tegangan tertentu. Proses oksidasi-reduksi ini bertujuan untuk mendestabilkan ion agar memudahkan proses pengendapan serta mengurangi sifat racun dari ion tersebut.

Reaksi-reaksi yang terjadi pada proses elektrokoagulasi sebagai berikut.

Reaksi redoks di katoda (elektroda negatif):

$$
\begin{aligned}
& \mathrm{Cu}^{2+}+2 \mathrm{e}^{-} \rightarrow \mathrm{Cu} \\
& 2 \mathrm{H}_{2} \mathrm{O} \rightarrow 4 \mathrm{H}^{+}+\mathrm{O}_{2}+4 \mathrm{e}^{-}
\end{aligned}
$$

Reaksi redoks di anoda (elektroda positif):

$$
\begin{aligned}
& \mathrm{Cu} \rightarrow \mathrm{Cu}^{2+}+2 \mathrm{e}^{-} \\
& 2 \mathrm{H}_{2} \mathrm{O}+2 \mathrm{e}^{-} \rightarrow 2 \mathrm{OH}^{-}+\mathrm{H}_{2}
\end{aligned}
$$

Pada anoda yang merupakan tembaga akan mengalami terjadi reaksi oksidasi air menjadi gas oksigen $\left(\mathrm{O}_{2}\right)$, sedangkan di katoda terjadi reduksi air menjadi gas hidrogen $\left(\mathrm{H}_{2}\right)$. Ion $\mathrm{Cu}^{2+}$ yang berasal dari pelarutan anoda akan direduksi dengan ion $\mathrm{OH}$ membentuk cuprum hidroksida $\mathrm{Cu}(\mathrm{OH})_{2}$ menurut reaksi:

$$
\mathrm{Cu}^{2+}+2 \mathrm{OH}^{-} \rightarrow \mathrm{Cu}(\mathrm{OH})_{2}
$$

Berdasarkan reaksi tersebut, pada anoda akan dihasilkan gas, buih dan flok $\mathrm{Cu}(\mathrm{OH})_{2}$ yang kemudian menggumpalkan padatan tersuspensi sehingga air menjadi jernih. Gelembung gas $\mathrm{O}_{2}$ dan $\mathrm{H}_{2}$ yang terbentuk akan membantu mendorong polutan mengapung ke permukaan. Peristiwa ini disebut dengan elektroflotasi.

Menurut Ge (2004) penyisihan surfaktan pada proses elektrokoagulasi terjadi karena adanya adsorpsi surfaktan pada permukaan partikel. Hal ini menyebabkan terbentuknya permukaan hydropobic yang menyebabkan partikel dalam air limbah akan naik ke permukaan dengan bantuan gelembung gas yang terbentuk.

\section{Membran}

Membran adalah lapisan tipis antara dua fase fluida yaitu fase umpan (feed) dan fasa permeat yang bersifat sebagai penghalang (barrier) terhadap suatu spesi tertentu, yang dapat memisahkan zat dengan ukuran yang berbeda. Membran dapat menahan spesi tertentu yang lebih besar dari ukuran pori membran dan melewatkan spesi lain dengan ukuran lebih kecil. Berdasarkan sifat ini, membran disebut bersifat semipermeabel. Sifat selektif dari membran ini dapat digunakan dalam proses pemisahan.

Pemisahan dengan membran dapat memindahkan komponen berdasarkan sifat fisik dan kimia dari membran serta komponen yang dipisahkan. Perpindahan ini terjadi karena adanya gaya dorong (driving force) dalam umpan yaitu beda tekanan $(\Delta \mathrm{P})$, beda konsentrasi $(\Delta \mathrm{C})$, beda potensial listrik $(\Delta \mathrm{E})$ dan beda temperatur $(\Delta \mathrm{T})$ serta selektifitas membran yang dinyatakan dengan rejeksi. Gambar 5 menggambarkan skema pemisahan oleh membran (Mulder,1996).

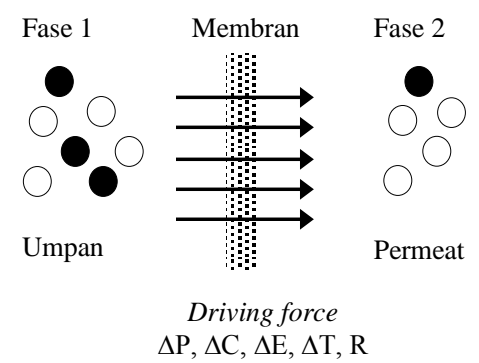

Gambar 5. Skema pemisahan oleh membran (Mulder,1996).

Membran dapat membatasi pengangkutan berbagai spesi berdasarkan sifat fisik dan kimianya secara selektif sehingga diharapkan zat pencemar seperti surfaktan dan fosfat dapat terdegradasi secara maksimal. Teknologi membran membutuhkan energi rendah, tidak menghasilkan kontaminan dan polutan, lahan 
yang diperlukan relatif kecil dan mudah dikombinasikan dengan produk teknologi lain (Mulder, 1996).

Berdasarkan bahannya, membran dibedakan menjadi membran polimer dan membran anorganik. Pada membran polimer, bahan polimer yang umum digunakan adalah selulosa dan turunannya (selulosa asetat), polisulfon, poliamida, poliakrilonitril (Wenten, 1999). Selulosa asetat dan turunannya banyak digunakan sebagai bahan polimer membran karena sifatnya yang ramah lingkungan.

\section{Biofilter}

Biofilter adalah reaktor yang dikembangkan dengan prinsip tumbuh dan berkembangnya mikroba pada suatu media filter dan membentuk lapisan biofilm (attached growth) (Slamet dan Masduqi, 2000). Proses biofilter dilakukan dengan mengalirkan air limbah ke dalam reaktor biologis yang telah diisi media penyangga sebagai pengembangbiakkan mikroorganisme. Zat polutan di dalam air limbah, seperti fosfor akan terdifusi ke dalam lapisan biofilm yang melekat pada permukaan media.

Metode biofilter menggunakan tanaman yang memiliki kelompok mikroorganisme rhizosfer, yaitu kelompok mikroba yang hidup bersimbiosis di sekitar akar tanaman, baik tanaman di tanah maupun air. Mikroba rhizosfer dapat bahan organik maupun anorganik pada limbah (Waluyo, 2005).

Secara umum, media biofilter yang digunakan berupa bahan organik atau anorganik. Media biofilter dari bahan organik biasanya berbentuk jaring, tali, butiran tak teratur, papan dan bentuk sarang tawon. Untuk media anorganik, media dapat berupa batu pecah, kerikil, marmer atau batu tembikar.

Material organik yang terdiri dari mikroorganisme terlekat pada matriks polimer yang dibentuk oleh mikroorganisme itu sendiri disebut dengan biofilm. Ketebalan lapisan biofilm berkisar $100 \mu \mathrm{m}-10 \mu \mathrm{mm}$ (Barros, 2000). Lapisan biofilm yang sudah terbentuk sempurna akan tersusun dalam tiga lapisan kelompok bakteri, yaitu jamur pada lapisan terluar, lapisan tengah adalah jamur dan alga dan lapisan terdalam adalah bakteri, jamur dan algae (Slamet dan Masduqi, 2000).

Ketersediaan unsur karbon (C), Nitrogen $(\mathrm{N})$, dan Fosfor $(\mathrm{P})$ sebagai nutrien dapat mempengaruhi pertumbuhan biofilm. Metcalf dan Eddy (2004) melaporkan bahwa pertumbuhan lapisan biofilm dapat mencapai ketebalan antara 100 mikro meter sampai 10 mm tergantung pada kondisi tempat tumbuh biofilm.

Gambar 6 berikut merupakan contoh reaktor biofilter dengan kombinasi tanaman bambu air yang dilaporkan oleh Sutanto (2015).

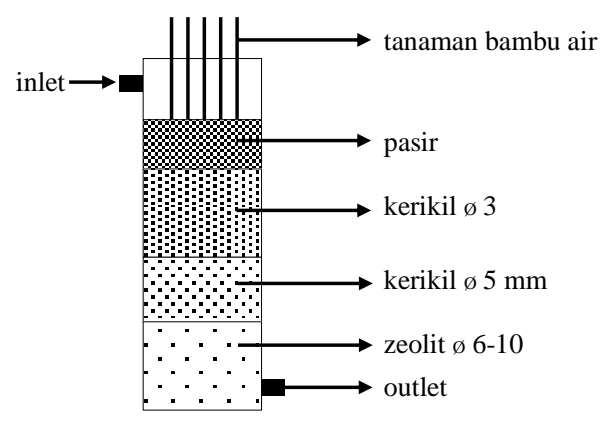

Gambar 6. Reaktor biofilter kombinasi tanaman bambu air

(Sutanto, 2015)

Biofilter terjadi dalam 2 tahap yaitu proses aklimatisasi atau penyemaian bakteri dan proses running. Proses aklimatisasi dilakukan dengan merendam media dalam wadah dengan air limbah laundry yang dibiarkan mengalami kontak langsung dengan udara. Hal ini bertujuan untuk menumbuhkan bakteri aerob pembentuk biofilm. Pertumbuhan biofilm ini diamati setelah 8 sampai 14 hari yang ditandai dengan ditandai licinnya permukaan media (Rizki, 2012). Media ini kemudian dipindahkan pada reaktor biofilter untuk proses running,yaitu pengambilan data pada selang waktu yang ditentukan. Data diambil dari pemeriksaan sampel yang diambil dari outlet.

\section{PENUTUP}

Surfaktan dan fosfat merupakan kandungan yang paling banyak terdapat dalam limbah laundry. Hal ini dikarenakan kedua zat tersebut adalah komponen utama dalam detergen yang digunakan pada jasa 
laundry. Beberapa metode yang telah dilaporkan dapat menurunkan kadar surfaktan dan fosfat dalam limbah laundry adalah biodegradasi, elektrokoagulasi, membran dan biofilter.

\section{DAFTAR PUSTAKA}

Budiawan, Fatisa, Y., Khairani N., 2009, Optimasi Biodegradabilitas dan Uji Toksisitas Hasil Degradasi Surfaktan Linear Alkilbenzena Sulfonat (LAS) sebagai Bahan Deterjen Pembersih, Makara Sains, 13 (2), 125-133.

Hudori, Soewondo, P., 2009, Pengolahan Deterjen Menggunakan Teknologi Elektrokoagulasi dengan Elektroda Aluminium, Jurnal Sains dan Teknologi Lingkungan, 1(2), 117-125.

Wardhana, I. W., Siwi, D. H., dan Ika, D. R., 2013, Penggunaan Karbon Aktif dari Sampah Plastik untuk Menurunkan Kandungan Phosphat pada Limbah Cair (Studi Kasus: Limbah Cair Industri Laundry di Tembalang, Semarang), Jurnal Presipitasi , 10 (1), 30-40.

Sutanto, H. B., 2015. Studi Pengolahan Air Limbah Industri Jasa Laundry menggunakan Kombinasi Biofilter dan Tanaman Bambu Air. Laporan Penelitian. Fakultas Bioteknologi, Universitas Kristen Duta Wacana, Yogyakarta.

Putra, I. K. S., 2015, Penurunan Kadar COD, Surfaktan dan Fosfat Limbah Laundry dengan Biosistem Tanaman, Skripsi, Fmipa, Universitas Udayana, Denpasar.

Astuti, S. W., Sinaga, M. S, 2015, Pengolahan Limbah Laundry Menggunakan Metode Biosand Filter untuk Mendegradasi Fosfat, Jurnal Teknik Kimia USU, 4 (2), 53-58.

Nasution, S. P. P., Karnaningroem, N., Pemulihan Kualitas Air Limbah Laundry dengan Reaktor Biofilter, Artikel Hasil Penelitian, Fakultas Teknik Sipil dan Perencanaan, Institut Teknologi Sepuluh Nopember, Surabaya.

Kusumo, A. H., Razif, M., Penurunan Konsentrasi Surfaktan dalam Limbah
Cair Laundry dengan Adsorpsi Menggunakan Arang Batok Kelapa (Coconut Shells) Komersil, Artikel Hasil Penelitian, Fakultas Teknik Sipil dan Perencanaan, Institut Teknologi Sepuluh Nopember, Surabaya.

Utami, A. R., 2013, Pengolahan Limbah Cair Laundry dengan Menggunakan Biosand Filter dan Activated Carbon, Jurnal Teknik Sipil Untan, 13 (1), 5971.

Yunarsih, N. M., 2013, Efektifitas Membran Khitosan dari Kulit Udang Galah (Macrobanchium rosenbergii) untuk Menurunkan Fosfat dalam Air Limbah Laundry, Tesis, Program Pascasarjana, Universitas Udayana, Denpasar.

Slamet, A., dan Masduqi, A., 2000, Satuan Proses, Institut Teknologi Sepuluh Nopember, Surabaya

Wandhana, R., 2013, Pengolahan Air Limbah Laundry Secara Alami (Fitoremediasi) Dengan Tanaman Kayu Apu (Pistia Stratiotes), Skripsi, Teknik Lingkungan, Universitas Pembangunan Nasional "Veteran", Jawa Timur.

Smulders, E., 2002, Laundry Detergents, Wiley-VCH Verlag $\mathrm{GmbH}$, Weinheim, Germany.

Mulder, M., 1996, Basic Principles of Membrane Technology, Kluwer Academic, Netherland.

D. Prats, D., Lopez, C., Vallejo, D., Varo, P., dan Leon, V. M., 2006, J. Surfact. Det., 9, 69-75.

Peinado, M. S., Lopez, J. G., Toledo, M. V. M., Pozo, dan C., Rodelas, B., 2009, Environ. Sci. Pollut. Res., 30.

WHO (World Health Organization), 1996, Linear Alkylbenzene Sulfonates and Related Compounds, Environmental Health Criteria 169, International Programme on Chemical Safety (IPCS), Geneva.

Ge, J., Qu, J., Lei, P., dan Liu, H., 2004, New Bipolar ElectrocoagulationElectroflotation Process for The Treatment of Laundry Wastewater, Separation and Purification Technology, 36, 33-39. 
Holt, P. K., Barton, G. W., dan Mitchell, C. A., 2001, The role of current in determining pollutant removal in a batch electrocoagulation reactor. In 6th World Congress of Chemical Engineering, Conference Media CD, Melbourne, Australia.

Mollah, M. Y. A., Morkovsky, P., Gomes, J. A. G., Kesmez, M., Parga, J., dan Cocke, D. L., 2004, Fundamentals, Present and FuturePerspectives of Electrocoagulation, Journal of Hazardous Materials, B114, 199-210.

Wenten, I. G., 1999, Teknologi Membran Industri, ITB Press, Bandung.

Metcalf dan Eddy, 1991, Waste Water Engineering Treatment, Disposal and Reuse, Mc. Graw-Hill, Inc., New York.

Sutanto, H., 1996, Purification of Wastewater from Detergent Factory by a Biological Rotor, International Institute for Infrastructural, Hydraulic and Environmental Enggineering.

Widiyani, P., 2010, Dampak dan Penanganan Limbah Deterjen, Fakultas Kedokteran Hewan, Institut Pertanian Bogor, Bogor.

Barros, L. A. F., Filho, L.S., dan Peres, A. E. C., 2000, Technical Note Plant PracticeInnovations In A Phospate Concentrator. Dept of Minning Engineering, USP, Brazil.

Slamet, A., dan Masduqi, A., 2000, Satuan Proses, Fakultas Teknik Sipil dan
Perencanaan, Institut Teknologi Sepuluh Nopember, Surabaya.

Rizky, A., 2012, Penurunan Kadar COD Air Limbah Pencucian Motor dengan Biofilter, Artikel Hasil Penelitian, Fakultas Teknik Sipil dan Perencanaan, Institut Teknologi Sepuluh Nopember, Surabaya.

Waluyo, L., 2005, Mikrobiologi Lingkungan, Universitas Muhammadiyah Malang, Malang.

Puspitahati, C., 2012, Studi Kinerja Biosand Filter dalam Mengolah Limbah Laundry dengan Parameter Fosfat, Jurnal Jurusan Teknik Lingkungan, Fakultas Teknik Sipil dan Perencanaan, Institut Teknologi Sepuluh Nopember, Surabaya.

Budiany Rachmawati, B., Surya, Y. P., Mirwan, M., Proses Elektrokoagulasi Pengolahan Limbah Laundry, Jurnal Ilmiah Teknik Lingkungan, 6 (1), 1522.

Suastuti, Ni G. A. M. D. A., Suarsa, I. W., dan Putra R. D. K., 2015, Pengolahan Larutan Deterjen Dengan Biofilter Tanaman Kangkungan (Ipomoea Crassicaulis) dalam Sistem Batch (Curah) Teraerasi, Jurnal Kimia, 9 (1), 98-104.

Aufiyah dan Damayanti, A., 2013, Pengolahan Limbah Laundry Menggunakan Membran Nanofiltrasi Aliran Cross Flow untuk Menurunkan Kekeruhan dan Fosfat, Jurnal Teknik POMITS, 2 (2). 